\title{
Yeast culture increased plasma niacin concentration, evaporative heat loss, and feed efficiency of dairy cows in a hot environment
}

\author{
Julia D. L. Dias, ${ }^{*}$ Rayana B. Silva, ${ }^{*} \dagger$ Tatiane Fernandes, ${ }^{*}$ Eugenio F. Barbosa, ${ }^{*}$ Larissa E. C. Graças, ${ }^{*}$ \\ Rafael C. Araujo, $\ddagger$ Renata A. N. Pereira, $\nmid \S$ and Marcos N. Pereira* ${ }^{*}{ }^{1}$ \\ *Department of Animal Sciences, University of Lavras, Lavras, MG 37200-000, Brazil \\ †Better Nature Research Center, ljaci, MG 37205-000, Brazil \\ †GRASP Indústria e Comércio Ltda., Curitiba, PR 81260-000, Brazil \\ §Minas Gerais Agricultural Research Enterprise (Epamig), Lavras, MG 37200-000, Brazil
}

\begin{abstract}
The supplementation of dairy cows with yeast culture may increase diet digestibility, plasma niacin concentration, heat dissipation, and lactation performance. Our objective was to evaluate the response of Holstein cows in late lactation $(234 \pm 131 \mathrm{~d}$ in milk $)$ to dead yeast culture (YC, 15 g/d, Factor SC, GRASP, Saccharomyces cerevisiae) during Brazilian summer (temperaturehumidity index $>68$ for $92.2 \%$ of the time). Thirty-two cows were individually fed a standard total mixed ration for $14 \mathrm{~d}$ and control (CTL) or YC treatments for 35 $\mathrm{d}$, in a covariate adjusted complete randomized block design. Response was evaluated in wk 5 or as repeated measures over time. Cows were milked 3 times per day and treatments (YC or placebo) were orally dosed to each cow before each milking. Plasma niacin was 1.50 for CTL and $1.66 \mu \mathrm{g} / \mathrm{mL}$ for YC. The YC reduced rectal temperature, respiration rate, and skin temperature, whereas it tended to increase sweating rate. The proportion of cows with rectal temperature $\geq 39.2^{\circ} \mathrm{C}$ on CTL and YC was, respectively, 8 and $0 \%$ at 0730 h, 52 and $25 \%$ at $1500 \mathrm{~h}$, and 35 and $26 \%$ at $2200 \mathrm{~h}$. Plasma glucose was increased by YC. The total-tract apparent digestibility of nutrients, plasma urea $\mathrm{N}$ concentration, molar proportion of ruminal VFA, and urinary allantoin excretion were not affected by YC. Cows fed YC were less selective against feed particles $>19 \mathrm{~mm}$ in the morning, in the afternoon were more selective against long feed particles and in favor of particles $<8 \mathrm{~mm}$, and refused short particles at night. Milk yield was not different $(30.5 \mathrm{~kg} / \mathrm{d}$ for CTL and $30.2 \mathrm{~kg} / \mathrm{d}$ for YC). Feeding YC reduced dry matter intake (20.3 vs. 19.4 $\mathrm{kg} / \mathrm{d}$ ) and the digestible organic matter intake (15.6 vs. $13.9 \mathrm{~kg} / \mathrm{d}$ ). The inclusion of YC increased the ratios of milk to dry matter intake (1.50 vs. 1.64$)$ and energy-
\end{abstract}

Received December 19, 2017.

Accepted February 27, 2018.

${ }^{1}$ Corresponding author: mpereira@dzo.ufla.br corrected milk to dry matter intake (1.81 vs. 1.98). The covariate adjusted body weight $(648 \mathrm{~kg})$ and body condition score (3.0) did not differ. Milk solids yields and concentrations, linear somatic cell count, and milk urea $\mathrm{N}$ were also similar. The supplementation of $\mathrm{YC}$ increased plasma niacin concentration, body heat loss, and feed efficiency of late lactation dairy cows by reducing intake at similar milk yield.

Key words: body temperature, digestibility, heat stress, Saccharomyces cerevisiae

\section{INTRODUCTION}

Although the effect of yeast supplementation on lactation performance seems to be variable across experiments, thorough meta-analysis suggested that the average effect is positive (Desnoyers et al., 2009; Poppy et al., 2012). Additives classified as dead yeast culture are not dependent on the presence of viable (active) yeast cells to have physiological action (Poppy et al., 2012). Yeast culture may provide growth factors for ruminal microorganisms, capable of inducing improvement in nutrient digestibility and reduction in lactic acid accumulation in rumen fluid (Chaucheyras-Durand et al., 2008). Recently, it was shown that the supplementation of dairy cows with live and dead yeast increased the concentration of niacin in plasma (Salvati et al., 2015), capable of having positive effects on peripheral circulation and heat increment dissipation by evaporative loss (Zimbelman et al., 2010, 2013). Yeast cell wall polysaccharides also have the potential to act positively on the immune function of dairy cows (Zaworski et al., 2014).

The selection for high milk yield has increased the sensitivity of dairy cows to heat stress because greater yield increases digestible nutrient intake and metabolic heat production (Kadzere et al., 2002). Heat stress causes major financial loss to the global dairy industry by reducing milk yield, reproductive efficiency, and longevity of dairy cows (St. Pierre et al., 2003). Cows subjected to heat stress have reduced feed intake, have 
a propensity to develop ruminal acidosis (Mishra et al., 1970), and are more dependent on glucose as energy substrate (Baumgard and Rhoads, 2012). Heat stress can also cause immune deficiency (Bradford et al., 2015) and increased maintenance energy requirement (Fuquay, 1981).

The positive effect of yeast supplementation on the performance of dairy cows subjected to heat stress has been postulated for quite some time (Huber et al., 1994). Cows under heat stress appear to have a greater positive response in milk yield to yeast-based products (Bruno et al., 2009; Moallem et al., 2009; Salvati et al., 2015) than would be predicted from meta-analysis of the literature on yeast supplementation (Desnoyers et al., 2009; Poppy et al., 2012). Positive effects of yeast-based products on feed efficiency of dairy cows under heat stress have been observed, either driven by increased milk yield at similar intake (Moallem et al., 2009; Liu et al., 2014) or reduced intake at similar yield (Schingoethe et al., 2004). However, when dairy cows were subjected to a short-term thermal challenge in climatic chambers, the supplementation of live yeast and enzymes reduced the rectal temperature, but did not attenuate the negative effect of the excessive heat load on lactation performance and intake (Shwartz et al., 2009).

We evaluated the effect of dead yeast culture on feed efficiency, nutrient digestibility, plasma metabolites, body heat dissipation, and chewing and ingestion behavior of dairy cows subjected to a hot environment during Brazilian summer. We hypothesized that yeast culture would have positive effects on nutrient utilization and heat dissipation capable of inducing improvement in lactation performance and feed efficiency of dairy cows.

\section{MATERIALS AND METHODS}

The protocol was approved by the University of Lavras Bioethic Committee in Utilization of Animals.

\section{Location, Cows, and Experimental Design}

The experiment was conducted from November 15 to December 28, 2015, in an open-walled, sand-bedded tiestall barn with fans and high-pressure sprinklers at the Better Nature Research Center (http://www .holandesflamma.com.br/), located at Ijaci, Minas Gerais, Brazil. The research center is located at $846 \mathrm{~m}$ above sea level, $21^{\circ} 09^{\prime} 52.41^{\prime \prime}$ latitude south, and $44^{\circ}$ $55^{\prime}$ 52.40" longitude west. Environmental temperature and relative humidity at the center of the barn were measured at 30-min intervals with a digital thermometer (EasyLog-USB-2-LCD, Lascar Electronics, Salis- bury, United Kingdom) located $2.5 \mathrm{~m}$ from the floor. The temperature-humidity index (THI) was calculated according to Yousef (1985): $\mathrm{THI}=\mathrm{T}+0.36 \times \mathrm{DP}+$ 41.2 , where $\mathrm{T}=$ temperature $\left({ }^{\circ} \mathrm{C}\right)$ and $\mathrm{DP}=$ dew point $\left({ }^{\circ} \mathrm{C}\right)$.

Thirty-two Holstein cows $(234 \pm 131$ DIM at the beginning of the experiment), 10 primiparous, were individually fed the same TMR for a 2-wk standardization period and data obtained on d 11 to 14 were used as a covariate in the statistical model. Cows were paired blocked based on parity and milk yield and assigned to a treatment for a 35-d comparison period, in a covariate adjusted randomized block design with repeated measures over time. Treatments were control (CTL) or yeast culture (YC; Factor SC, GRASP Indústria e Comércio Ltda, Curitiba, Brazil). The product is marketed as dead yeast culture with growing medium and metabolites. Paper capsules containing $5 \mathrm{~g}$ of the $\mathrm{YC}$ were orally given to each cow 3 times per day, before milking ( $15 \mathrm{~g} /$ cow per $\mathrm{d})$. Cows on CTL received paper only.

The concentrations of live and dead cells per gram of product were determined. The yeast culture was rehydrated in peptone water $(0.1 \%)$ warmed to $30^{\circ} \mathrm{C}$ and allowed to stand for 10 min before the addition of the same volume of a methylene blue solution $(0.01 \%)$. Cell count was performed in a Neubauer chamber with a bright field optical microscope (400× magnification), according to the recommendations of Lee et al. (1981). Dead yeast cells stain dark blue, whereas live cells stain light blue due to the difference in cell permeability to the dye. The niacin concentration of the sample was determined by HPLC in a commercial laboratory (Eurofins Alac, Garibaldi, Brazil).

\section{Feed Management, Measurements, and Analytical Procedures}

The composition of the experimental diet is listed in Table 1. The same TMR batch was offered to all cows during the comparison period. The TMR was prepared 2 times per day in a vertical stationary vertical mixer (Unimix 1200, Casale, São Carlos, Brazil) and cows had access to new feed at 0700 and $1300 \mathrm{~h}$. The silage DM concentration was monitored weekly with an electric moisture tester (Koster Crop Tester, Strongsville, OH) and diet were adjusted accordingly. Individual cow intake was assessed daily by recording the amount of feed offered and orts (as-fed basis). The feed was offered in sufficient quantity to obtain at least $10 \%$ of the offered as daily refusals.

Samples of dietary ingredients were collected daily and composite samples made per week. Likewise, ort samples were collected daily and composited per cow 
per week. Composite samples were dried in forced-air oven at $55^{\circ} \mathrm{C}$ for $72 \mathrm{~h}$ and ground through a 1-mm mesh screen (Wiley mill, Thomas Scientific, Swedesboro, NJ). The DM concentration was determined by drying at $100^{\circ} \mathrm{C}$ for $24 \mathrm{~h}$. The composition of the consumed diet in nutrients was calculated for each cow based on the composition of offered ingredients and orts on a DM basis. The CP concentration was determined with a micro Kjeldahl apparatus (AOAC International, 2012), ash by incineration at $550^{\circ} \mathrm{C}$ for $8 \mathrm{~h}$, and the ash-free NDF by filtration in porous crucibles with heat-stable

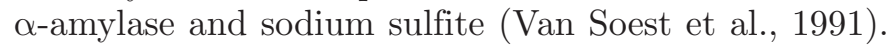
The ether extract was analyzed as in AOAC International (2012) and starch was enzymatically determined according to Hall (2009). The NFC fraction was calculated as $100-(\mathrm{CP}+$ ether extract + ash $+\mathrm{NDF})$.

Cows were milked 3 times per day in an adjacent herringbone parlor starting at 0500, 1300, and 2000 $\mathrm{h}$ with milk yield recorded daily. Proportional milk samples from each milking were obtained on d 11 to 14 of the standardization period and on $\mathrm{d} 6$ and 7 of each week of the comparison period. Milk solids, SCC, and

Table 1. Ingredient composition and particle size of the offered TMR and nutrients of the consumed TMR (\% of DM) of control (CTL) and yeast $(\mathrm{YC})$ treatments

\begin{tabular}{|c|c|c|c|}
\hline Item & CTL & $\mathrm{YC}$ & Both \\
\hline Corn silage & & & 39.5 \\
\hline Oat hay & & & 3.9 \\
\hline Finely ground corn rehydrated and ensiled & & & 17.6 \\
\hline Soybean meal ( $46.3 \% \mathrm{CP})$ & & & 14.7 \\
\hline Whole cottonseed & & & 8.4 \\
\hline High-bypass soybean meal $(48.1 \% \mathrm{CP})^{1}$ & & & 3.9 \\
\hline Citrus pulp & & & 10.1 \\
\hline Limestone & & & 0.9 \\
\hline Magnesium oxide & & & 0.3 \\
\hline $\mathrm{NaCl}$ & & & 0.2 \\
\hline Minerals and vitamins ${ }^{2}$ & & & 0.5 \\
\hline $\mathrm{CP}$ & 16.6 & 16.6 & \\
\hline $\mathrm{NDF}$ & 29.1 & 29.0 & \\
\hline Forage NDF & 22.8 & 22.9 & \\
\hline Starch & 26.7 & 26.6 & \\
\hline Ash & 5.4 & 5.4 & \\
\hline Ether extract & 5.0 & 5.0 & \\
\hline $\mathrm{NFC}^{3}$ & 42.8 & 42.8 & \\
\hline DM, $\%$ of as fed & 44.8 & 45.0 & \\
\hline Feed particles $>19 \mathrm{~mm},{ }^{4} \%$ of as fed & & & $7.3 \pm 1.9$ \\
\hline Feed particles 8 to $19 \mathrm{~mm}, \%$ of as fed & & & $36.7 \pm 1.9$ \\
\hline Feed particles $<8 \mathrm{~mm}, \%$ of as fed & & & $56.0 \pm 1.8$ \\
\hline
\end{tabular}

${ }^{1}$ SoyPass BR, Cargill, Uberlândia, Brazil.

${ }^{2} 210.5 \mathrm{~g} / \mathrm{kg}$ of Ca, $156 \mathrm{~g} / \mathrm{kg}$ of P, $30.4 \mathrm{~g} / \mathrm{kg}$ of $\mathrm{Mg}, 39.5 \mathrm{~g} / \mathrm{kg}$ of S, 150 $\mathrm{mg} / \mathrm{kg}$ of Co, $2,000 \mathrm{mg} / \mathrm{kg}$ of Cu, $5,000 \mathrm{mg} / \mathrm{kg}$ of $\mathrm{Mg}, 11,903 \mathrm{mg} / \mathrm{kg}$ of $\mathrm{Zn}, 82 \mathrm{mg} / \mathrm{kg}$ of Se, $200 \mathrm{mg} / \mathrm{kg}$ of I, 1,000 kUI/ $\mathrm{kg}$ of vitamin A, 220 $\mathrm{kUI} / \mathrm{kg}$ of vitamin D, and $6,200 \mathrm{UI} / \mathrm{kg}$ of vitamin E.

${ }^{3}$ Nonfiber carbohydrates calculated as $100-(\mathrm{CP}+$ ether extract + ash + NDF).

${ }^{4}$ Orifice diameter of sieves of the Penn State Particle Separator. Mean \pm SD of 30 TMR samples.
MUN were analyzed by mid-infrared analysis (Bentley Instruments Inc., Chaska, MN) in a commercial laboratory (Laboratory of the Paraná State Holstein Breeders Association, Curitiba, Brazil). Milk energy secretion (Milk E; Mcal/d) was calculated as [(0.0929 × \% fat) $+(0.0547 \times \%$ protein $)+(0.0395 \times \%$ lactose $)] \times$ $\mathrm{kg}$ of milk (NRC, 2001, Equation 2-15). The secretion of ECM $(\mathrm{kg} / \mathrm{d})$ was calculated as follows: Milk E/0.70 (assumes $0.70 \mathrm{Mcal} / \mathrm{kg}$ of milk with $3.7 \%$ fat, $3.2 \%$ protein, and $4.6 \%$ lactose (a frequent goal for Holstein farms in Brazil). The $4 \% \mathrm{FCM}(\mathrm{kg} / \mathrm{d})$ was calculated with the Gaines equation (NRC, 2001): $0.4 \times \mathrm{kg}$ of milk $+15 \times \mathrm{kg}$ of fat. The BCS was the mean of the same 3 independent evaluators ( 1 to 5 scale, Wildman et al., 1982) on d 13 of the standardization period and on d $8,15,22,29$, and 35 of the comparison period. The BW was measured after the morning milking on $\mathrm{d} 13$ and 14 of the standardization period and $\mathrm{d} 6$ and 7 of each week of the comparison period (mean value was used per week). The daily BW gain was calculated as the slope of the linear regression of BW over time.

Rectal and skin temperatures and the respiration rate were measured on d 4 and 7 of each week of the comparison period starting at 0730,1500 , and $2200 \mathrm{~h}$. Measurements were made randomly within block. Rectal temperature was measured with digital thermometers (G-Tech TH186 Onbo Eletronics, Shenzhen, China, accuracy of $0.1^{\circ} \mathrm{C}$ ). The respiration rate (breaths $/ \mathrm{min}$ ) was the mean of 3 consecutive 30-s flank movement counts. The skin temperature of shaved areas of the shoulder and flank were measured with an infrared thermometer (HighMed 88E, São Paulo, Brazil, accuracy of $0.1^{\circ} \mathrm{C}$ ), manually pointed at $20 \mathrm{~cm}$ from the skin.

The sweating rate was evaluated once per week (d 7) at $1500 \mathrm{~h}$, randomly within block. The colorimetric technique used paper discs impregnated with cobalt chloride (Schleger and Turner, 1965). Filter paper (Whatman no. 1, $11 \mu \mathrm{m}$ porosity) was immersed in a $10 \%$ cobalt chloride solution and then oven-dried at $105^{\circ} \mathrm{C}$ for $12 \mathrm{~h}$. Paper discs $(0.5 \mathrm{~cm}$ diameter) were cut and dried for $2 \mathrm{~min}$. Three discs were placed on histological slides and fixed with transparent adhesive tape. The slides with disks were immediately placed in a sealed glass containing silica. A $3 \times 10 \mathrm{~cm}$ rectangular area was shaved on the left flank of each cow, $10 \mathrm{~cm}$ below the lumbosacral vertebrae, $1 \mathrm{~d}$ before the measurement. The tape with discs was fixed over the shaved area. The time for each disc to change color from blue violet to light pink was recorded and the mean value was used to calculate the sweating rate $\left(\mathrm{g} / \mathrm{m}^{2} / \mathrm{h}\right)$ as $38,446.6 / \mathrm{T}$, where $\mathrm{T}$ is time in seconds (Schleger and Turner, 1965). The estimated body surface area $\left(\mathrm{m}^{2}\right)$ was as follows: $\mathrm{kg}$ of $\mathrm{BW}^{0.56} \times 0.15 \mathrm{~m}^{2} / \mathrm{kg}$ of $\mathrm{BW}^{0.56}$ 
(McLean, 1963). The total stored heat was (kcal): body temperature $\left({ }^{\circ} \mathrm{C}\right) \times$ specific heat of tissue $(0.80 \mathrm{kcal} /$ $\mathrm{kg}$ per $\left.{ }^{\circ} \mathrm{C}\right) \times \mathrm{BW}(\mathrm{kg})$ (Sawka and Castellani, 2007) Body temperature was $0.9 \times$ rectal temperature +0.1 $\times$ skin temperature (Sawka and Castellani, 2007). The evaporative heat loss $(\mathrm{kcal} / \mathrm{h})$ was sweating rate $\left(\mathrm{g} / \mathrm{m}^{2}\right.$ per $\mathrm{h}) \times$ body surface area $\left(\mathrm{m}^{2}\right) \times 0.58 \mathrm{kcal} / \mathrm{g}$ of sweat (Silanikove, 2000).

Jugular blood acid-base balance was analyzed on d 26 at $8 \mathrm{~h}$ after the morning feeding with an AGS 22 blood gas analyzer (Drake Eletrônica e Comércio Ltda, São José do Rio Preto, Brazil) less than $1 \mathrm{~h}$ after sampling. Blood samples were collected in heparinized vacuum tubes, within a 30-min period at random within block, and were kept on ice from sampling to analysis.

The total-tract apparent digestibility of DM, OM, NDF, non-NDF OM, and starch were determined on d 27 to 29 by total collection of feces in buckets. Feces were collected concurrent to defecation during three 8-h sampling periods and weighed. The second and third sampling periods were each delayed by $8 \mathrm{~h}$, thus representing a 24-h collection. Fecal aliquots (equal fresh weight basis) were immediately frozen along the collection period and a composite sample was formed per cow. Composite fecal samples were dried for $72 \mathrm{~h}$ at $55^{\circ} \mathrm{C}$ in a forced-air oven and ground through a $1-\mathrm{mm}$ mesh screen (Wiley mill, Thomas Scientific, Swedesboro, NJ). The DM concentration was determined by drying at $100^{\circ} \mathrm{C}$ for $24 \mathrm{~h}$. Concentrations of NDF, ash, and starch were determined as described previously. The daily digestible OM intake (DOMI) on d 27 to 29 of the experimental period was calculated.

Total urinary output was collected in buckets, simultaneously to fecal sampling, to estimate the relative ruminal microbial synthesis based on purine derivative excretion (mmol/d). A 20\% sulfuric acid solution (200 $\mathrm{mL}$ ) was added to $20-\mathrm{L}$ buckets and urine was added to it during the collection period. At the end of the 3 -d collection period, composite urine samples were diluted 1:5 with a $4 \%$ sulfuric acid solution and frozen at $-20^{\circ} \mathrm{C}$. Allantoin was analyzed according to Chen and Gomes (1992).

Blood samples were obtained from the coccygeal vessels on d 35 to determine the concentration of niacin in plasma. Blood was obtained $12 \mathrm{~h}( \pm 10 \mathrm{~min})$ after the morning feeding in vacuum tubes containing EDTA and centrifuged at 2,118 $\times g$ for 10 min to obtain plasma, which was kept at $-20^{\circ} \mathrm{C}$ until analysis. Plasma niacin concentration was analyzed with a VitaFast niacin microbiological assay (R-Biopharm, Darmstadt, Germany). Blood samples were also obtained on d 34 to determine the concentration of plasma urea N (PUN). Samples were obtained immediately before the first daily feeding and at 2 and $4 \mathrm{~h}( \pm 10 \mathrm{~min})$ after feeding. The PUN was analyzed with a laboratory kit (Urea 500, Doles Reagentes para Laboratórios, Goiânia, Brazil). Plasma glucose concentration was measured on d 21 and 35 on blood samples obtained $12 \mathrm{~h}$ after morning feeding with vacuum tubes containing EDTA and potassium fluoride. Glucose was analyzed with a laboratory kit (Glicose Enzimática Líquida, Doles Reagentes para Laboratórios).

On d 35 ruminal fluid samples were collected with a flexible oro-gastric tube. Samples were obtained $10 \mathrm{~h}$ ( $\pm 50 \mathrm{~min})$ after the morning feeding, at random within block. Ruminal fluid $\mathrm{pH}$ was measured immediately (Hanna pH 21 pH/mV meter, Hanna Instruments, Woonsocket, RI). A ruminal fluid sample was frozen in liquid nitrogen to suppress fermentation and stored at $-20^{\circ} \mathrm{C}$ until preparation for analysis of VFA by GC with a HP-FFAP capillary column (Agilent Technologies, Palo Alto, CA) according to Ferreira et al. (2016). Another sample was mixed to a $36 \%$ formaldehyde solution for protozoa counting. The sample for protozoa enumeration was stained and evaluated with an optical microscope in a Neubauer chamber according to Warner (1962) and Dehority (1984).

Chewing activity and feed sorting behavior were measured on d 30 to 32 , in which feed availability at $1300 \mathrm{~h}$ was increased to obtain daily refusals around $20 \%$ of the offered TMR to exacerbate the expression of sorting behavior (Dohme et al., 2008). Chewing activity was evaluated by visual observation of the buccal activities of each cow at 5-min intervals continuously for 3 consecutive 24 -h periods. Daily values were averaged per cow. Buccal activities evaluated were feed ingestion, water ingestion, rumination, and idleness. Ingestion and rumination per unit of DMI were calculated using the intake of the day in which chewing activity was evaluated. A meal was defined by at least 2 consecutive 5-min ingestion events following at least 10 min of idleness or rumination (Mullins et al., 2012). The intermeal interval was calculated by time not ingesting (rumination + idleness) divided by the number of meals/d minus 1 . The duration of the first daily meal (conditioned meal) was measured with a chronometer. Five evaluators observed the behavior of all cows after offering feed at $0700 \mathrm{~h}$ until the last cow finished its first meal. The proportions of daily TMR intake between 0700 and $1300 \mathrm{~h}, 1300$ and $1900 \mathrm{~h}$, and 1900 and $0700 \mathrm{~h}$ were measured.

Feed sorting behavior was evaluated according to Leonardi and Armentano (2003). The proportion of particles above the 19-mm mesh diameter screen and above and below the 8-mm mesh screen of the Penn State Particle Separator was evaluated at 0600 and 
$1300 \mathrm{~h}$ for the offered TMR and at 1200, 1900, and $0600 \mathrm{~h}$ for refusals. Feed refusals at $1200 \mathrm{~h}$ were mixed with feed offered at $1300 \mathrm{~h}$ for measurement of the offered TMR particle size of each cow. The predicted intake (as-fed basis) of particles on each screen was $\%$ TMR retained on screen $\times \mathrm{kg}$ of TMR consumed. The observed intake of particles was $\%$ TMR retained on screen $\times \mathrm{kg}$ of TMR offered $-\%$ orts retained on screen $\times \mathrm{kg}$ of orts. For the calculation of starch and NDF sorting behaviors, the predicted intake of a nutrient was $\%$ of nutrient in offered TMR DM $\times \mathrm{kg}$ of DMI. The observed intake was $\%$ of nutrient in offered TMR DM $\times \mathrm{kg}$ of offered TMR DM $-\%$ of nutrient in orts $\mathrm{DM} \times \mathrm{kg}$ of orts DM. The selection index was $100 \times$ (observed intake/predicted intake). Sorting values below $100 \%$ represent selective refusal, above $100 \%$ represent preferential intake, and equal to $100 \%$ represent no selection.

\section{Statistical Analysis}

The data were analyzed as repeated measures with the Mixed procedure of SAS statistical software (ver. 9.3; Littell et al., 1998) with the model $\mathrm{Y}_{\mathrm{ijk}}=\mu+\mathrm{CV}$ $+\mathrm{B}_{\mathrm{i}}+\mathrm{Y}_{\mathrm{j}}+\mathrm{T}_{\mathrm{k}}+\mathrm{Y} \times \mathrm{T}_{\mathrm{jk}}+\mathrm{e}_{\mathrm{ijk}}$, where $\mu=$ overall mean, $\mathrm{CV}=$ covariate (measure of the same variable at the end of the standardization period), $\mathrm{B}_{\mathrm{i}}=$ random block effect ( $\mathrm{i}=1$ to 16$), \mathrm{Y}_{\mathrm{j}}=$ fixed treatment effect $(\mathrm{j}=$ CTL or $\mathrm{YC}), \mathrm{T}_{\mathrm{k}}=$ fixed time effect $(\mathrm{k}=$ days or weeks), $\mathrm{Y} \times \mathrm{T}_{\mathrm{jk}}=$ interaction between treatment and time, and $\mathrm{e}_{\mathrm{ijk}}=$ residual error. For variables measured only during the comparison period, the same model was used, but without the covariate adjustment. The mean square for the effect of cow nested within treatment was used as the error to test the treatment effect. The best covariance structure was defined by the Akaike's information criterion among first-order autoregressive, unstructured, and compound symmetry. Degrees of freedom were estimated by using the Kenward-Roger option in the model statement. For BW change the model also did not contain the effect of time and its interaction with treatment. The frequency of distribution of rectal temperature $\geq 39.2^{\circ} \mathrm{C}$ was analyzed with the GENMOD procedure using logistic regression for binomial data. Statistical significance, trends, and weak trends were considered when $P \leq 0.05,0.05>P$ $\leq 0.10$, and $0.10>P \leq 0.15$, respectively.

\section{RESULTS}

The temperature, humidity, and THI inside the tiestall are reported in Figure 1. The mean THI during the 35 -d period was 72.7 , the proportion of time with THI $\geq 68$ was $92.2 \%$, and the average daily THI minimum was 67.6. The daily THI peaked at around $1400 \mathrm{~h}$ and the morning increase started at $0600 \mathrm{~h}$. The difference between the minimum and maximum daily THI was 12.9 .

The composition of the consumed diets on treatments CTL and YC was similar (Table 1). The dosage of $\mathrm{YC}$ was precisely force fed to each cow 3 times per day $(15 \mathrm{~g} /$ cow per d). The analyzed concentration of niacin in the product was $108 \mathrm{mg} / \mathrm{kg}$, resulting in a supplementation of yeast niacin of $1.62 \mathrm{mg} / \mathrm{cow}$ per $\mathrm{d}$ on treatment YC. The optical microscopy evaluation of the yeast cells stained with methylene blue showed that no live cells were present (Figure 2). Dead yeast cells were countable and the concentration was $1.9 \times$ $10^{9}$ dead cells of Saccharomyces cerevisiae per gram of growth medium, equivalent to $2.85 \times 10^{10}$ yeast cells/ cow per d.

Milk yield and composition, intake, and feed efficiency results are presented in Table 2. No significant $(P>0.05)$ interaction was observed between treatment and time for the variables evaluated. The $\mathrm{YC}$ reduced DMI $(P=0.04)$ and DOMI $(P=0.05)$, with no effect on lactation performance $(P \geq 0.21)$. The milk, ECM, and 4\% FCM to DMI ratios were all increased by YC $(P \leq 0.05)$. No difference between treatments was observed for the covariate adjusted BW $(P=0.18)$, daily BW gain $(P=0.54)$, BCS $(P=0.81)$, and the linear SCC $(P=0.99)$. The mean SCC equivalent was 185,000 cells $/ \mathrm{mL}$ of milk.

Plasma niacin concentration was increased by $\mathrm{YC}$ (Figure 3). The YC reduced $(P<0.01)$ rectal temperature at $1500 \mathrm{~h}$ (Table 3), the moment of the day of maximum temperature relative to 0730 and $2200 \mathrm{~h}$. The rectal temperature at $0730 \mathrm{~h}$ also tended $(P=0.09)$ to be reduced by $\mathrm{YC}$ and was numerically lower $(P=$ 0.17 ) than CTL at $2200 \mathrm{~h}$. The skin temperature at the shoulder and flank were reduced by $\mathrm{YC}$ at all times of measurement $(P \leq 0.04$, except for $P=0.07$ for flank temperature at $0730 \mathrm{~h}$,$) . The respiration rate was re-$ duced $(P \leq 0.04)$ by $\mathrm{YC}$ at 0730 and $1500 \mathrm{~h}$ and tended $(P=0.07)$ to be reduced at $2200 \mathrm{~h}$. The YC reduced $(P$ $\leq 0.05)$ the proportion of cows with rectal temperature $\geq 39.2^{\circ} \mathrm{C}$ (Table 4 ), defined as the threshold to suggest the occurrence of heat stress (Rhoads et al., 2009). The reduction in mean daily rectal temperature in response to $\mathrm{YC}(P=0.04)$ was accompanied by a weak trend $(P$ $=0.13$ ) of increased sweating rate (Table 5). The YC supplementation had no effect on the estimated evaporative heat loss $(P=0.21)$ and total stored heat $(P=$ 0.72 ), numerically higher and lower on YC than CTL, respectively. There was a trend $(P=0.10)$ for cows on $\mathrm{YC}$ to have lower partial pressure of $\mathrm{O}_{2}$ in jugular blood 

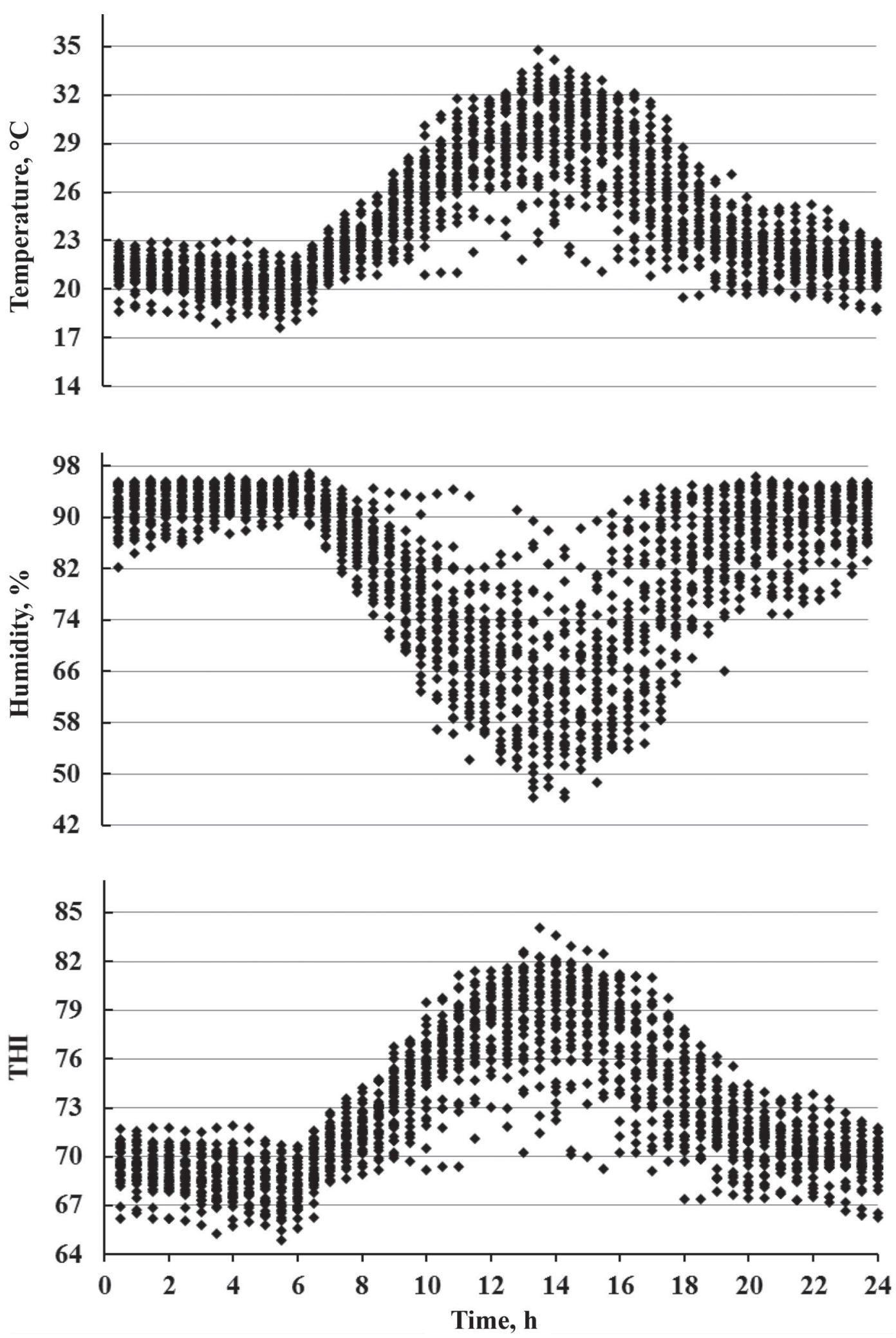

Figure 1. Temperature, humidity, and temperature-humidity index (THI) inside the tiestall. Temperature $=24.1 \pm 3.7^{\circ} \mathrm{C}(\mathrm{mean} \pm \mathrm{SD}$ ); humidity $=82.4 \pm 12.3 \%$; THI $=72.7 \pm 4.1$; THI $\geq 68=92.2 \%$ of the time; THI $\geq 72=44.6 \%$ of the time; minimum daily THI $=67.6 \pm 1.2$; maximum daily $\mathrm{THI}=80.5 \pm 1.8$. A total of 1,680 recordings at 30 -min intervals. 


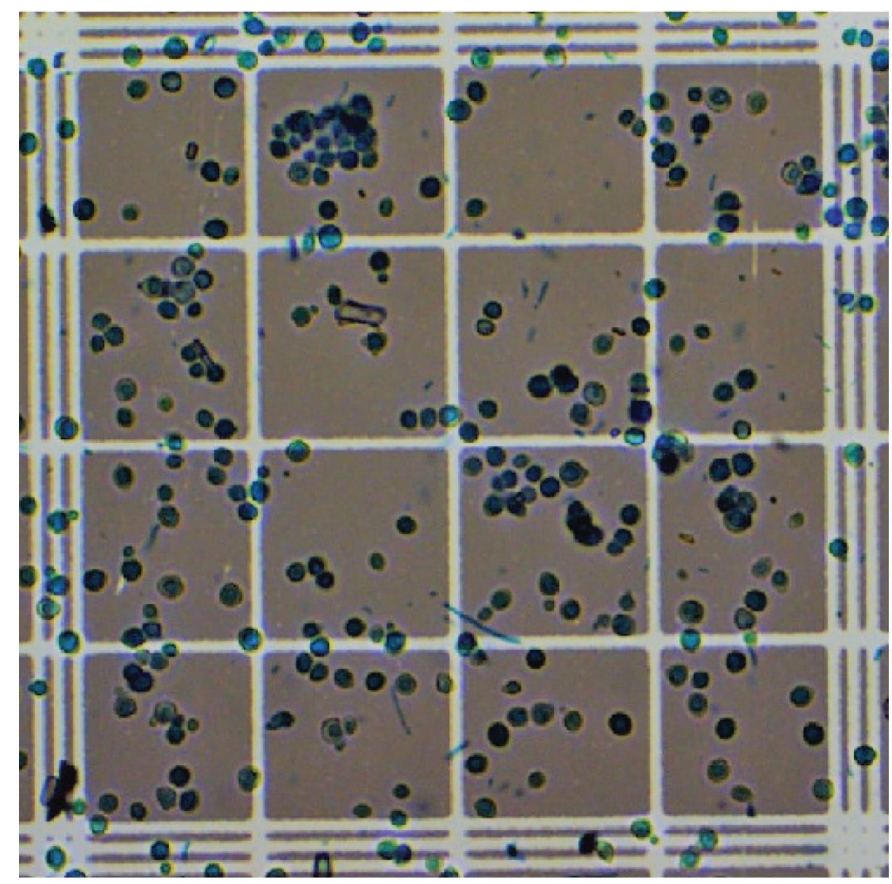

Figure 2. Yeast culture in a Neubauer chamber stained with methylene blue indicative of nonviable cells $(400 \times$ magnification). Color version available online.

than CTL (Table 6), probably reflecting the reduction in respiration rate (Table 3). Blood $\mathrm{pH}$ and the acidbase status were not affected by treatment $(P \geq 0.18)$.

Table 7 reports the total-tract apparent digestibility of nutrients and rumen microbial yield estimated by the daily urinary allantoin excretion. The supplementation of $\mathrm{YC}$ did not increase diet digestibility $(P \geq 0.17)$. The daily excretion of allantoin in urine did not respond to

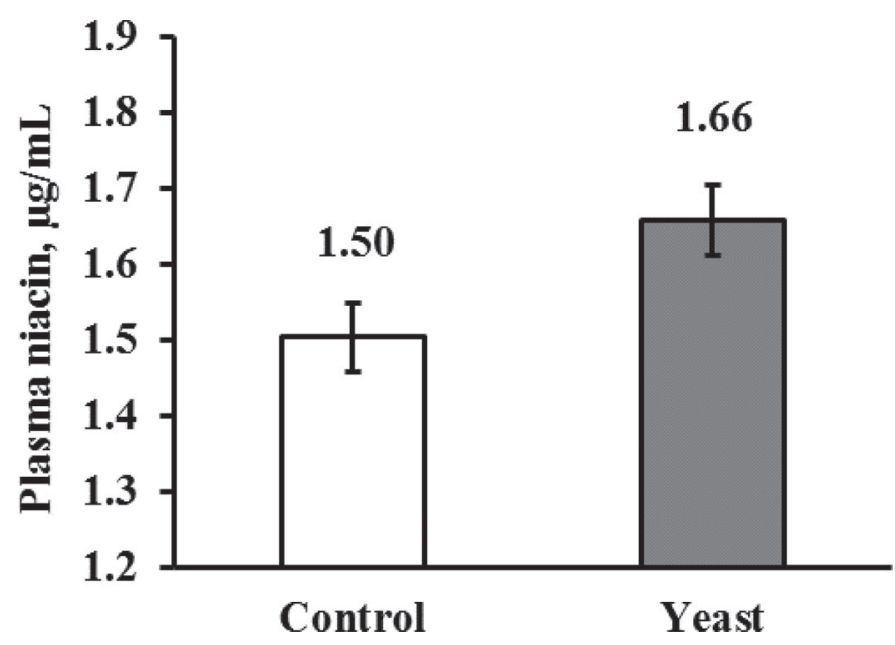

Figure 3. Plasma niacin concentration on d 35 at 12 h postfeeding on control and yeast treatments. $P=0.02$. Error bars represent SEM.
Table 2. Feed intake, lactation performance, MUN, feed efficiency, BW, BW change, BCS, and linear SCC of control (CTL) and yeast (YC) treatments

\begin{tabular}{|c|c|c|c|c|c|}
\hline \multirow[b]{2}{*}{ Item } & \multirow[b]{2}{*}{ CTL } & \multirow[b]{2}{*}{$\mathrm{YC}$} & \multirow[b]{2}{*}{ SEM } & \multicolumn{2}{|c|}{$P$-value ${ }^{1}$} \\
\hline & & & & Treatment & $\mathrm{T} \times \mathrm{W}^{2}$ \\
\hline DMI, $\mathrm{kg} / \mathrm{d}$ & 20.3 & 19.4 & 0.35 & 0.04 & 0.61 \\
\hline $\mathrm{DOMI},{ }^{3} \mathrm{~kg} / \mathrm{d}$ & 15.6 & 13.9 & 0.64 & 0.05 & \\
\hline Milk, $\mathrm{kg} / \mathrm{d}$ & 30.5 & 30.2 & 0.48 & 0.58 & 0.42 \\
\hline ECM, kg/d & 27.0 & 27.1 & 0.34 & 0.88 & 0.08 \\
\hline $4 \% \mathrm{FCM}, \mathrm{kg} / \mathrm{d}$ & 25.4 & 25.6 & 0.32 & 0.53 & 0.09 \\
\hline Fat, $\%$ & 2.94 & 2.96 & 0.036 & 0.62 & 0.15 \\
\hline Fat, $\mathrm{kg} / \mathrm{d}$ & 0.885 & 0.900 & 0.015 & 0.42 & 0.17 \\
\hline Protein, \% & 3.20 & 3.17 & 0.044 & 0.36 & 0.50 \\
\hline Protein, $\mathrm{kg} / \mathrm{d}$ & 0.963 & 0.949 & 0.008 & 0.42 & 0.20 \\
\hline Lactose, $\%$ & 4.50 & 4.49 & 0.027 & 0.79 & 0.65 \\
\hline Lactose, $\mathrm{kg} / \mathrm{d}$ & 1.369 & 1.376 & 0.015 & 0.73 & 0.40 \\
\hline Solids, \% & 11.57 & 11.52 & 0.215 & 0.47 & 0.48 \\
\hline Solids, kg/d & 3.492 & 3.503 & 0.040 & 0.83 & 0.11 \\
\hline Casein, \% & 2.45 & 2.43 & 0.079 & 0.46 & 0.34 \\
\hline Casein, kg/d & 0.751 & 0.718 & 0.029 & 0.21 & 0.19 \\
\hline MUN, mg/dL & 20.2 & 20.6 & 0.25 & 0.48 & 0.25 \\
\hline Milk/DMI & 1.50 & 1.64 & 0.087 & 0.05 & 0.85 \\
\hline $\mathrm{ECM} / \mathrm{DMI}$ & 1.32 & 1.38 & 0.015 & 0.01 & 0.40 \\
\hline $4 \% \mathrm{FCM} / \mathrm{DMI}$ & 1.25 & 1.31 & 0.130 & 0.01 & 0.42 \\
\hline ECM/DOMI & 1.81 & 1.98 & 0.075 & 0.13 & \\
\hline $\mathrm{BW}, \mathrm{kg}$ & 651 & 646 & 3.3 & 0.18 & 0.39 \\
\hline BW change, ${ }^{4} \mathrm{~kg} / \mathrm{d}$ & 0.57 & 0.48 & 0.113 & 0.54 & \\
\hline BCS, 1 to 5 & 3.00 & 2.99 & 0.048 & 0.81 & 0.37 \\
\hline Linear $\mathrm{SCC},{ }^{5} 1$ to 9 & 3.88 & 3.89 & 0.181 & 0.99 & 0.18 \\
\hline
\end{tabular}

${ }^{1} P<0.01$ for the effect of experimental week (1 to 5$)$ for all variables, except for linear SCC $(P=0.26)$ and BCS $(P=0.07)$.

${ }^{2} \mathrm{~T} \times \mathrm{W}=$ interaction between treatment and week.

${ }^{3}$ Digestible OM intake and feed efficiency on wk 5.

${ }^{4}$ Slope of the linear regression of BW over time.

${ }^{5}$ Equivalency of the linear scores; $3.88=184,000$ cells $/ \mathrm{mL}, 3.89=$ 185,000 cells $/ \mathrm{mL}$.

treatment $(P=0.38)$; however, a trend $(P=0.10)$ was observed for increased allantoin to DOMI ratio for cows supplemented with YC, suggestive of improvement in the efficiency of ruminal microbial synthesis. The lack of differences $(P \geq 0.42)$ in PUN postmorning feeding (Table 8) and MUN (Table 3) suggests that ruminal protein deamination or $\mathrm{N}$ capturing in microbial protein were not affected by YC. The ruminal VFA molar proportions, $\mathrm{pH}$, and protozoa concentration were not different $(P \geq 0.27)$ between CTL and YC treatments (Table 9$)$. The acetate to propionate ratio was similar $(P=0.31)$. The supplementation with YC increased $(P=0.01)$ the concentration of plasma glucose in wk 3 and 5 (Figure 4).

Chewing activity and ingestion behavior were not affected $(P \geq 0.17)$ by YC supplementation (Table 10). Cow posture, evaluated as daily laying time (Table 10), was also similar $(P=0.66)$. The alleviation of heat stress promoted by $\mathrm{YC}$ did not reflect in longer rumination or laying time. Cows on $\mathrm{YC}$ were less selective against feed particles $>19 \mathrm{~mm}$ in the morning $(P=$ $0.02)$, in the afternoon were more selective against long 
Table 3. Rectal and skin temperatures and respiration rate of cows fed the control (CTL) or yeast (YC) treatments

\begin{tabular}{|c|c|c|c|c|c|}
\hline \multirow[b]{2}{*}{ Item } & \multirow[b]{2}{*}{ CTL } & \multirow[b]{2}{*}{ YC } & \multirow[b]{2}{*}{ SEM } & \multicolumn{2}{|c|}{$P$-value } \\
\hline & & & & Treatment & Treatment $\times$ day $^{1}$ \\
\hline \multicolumn{6}{|c|}{ Rectal temperature, ${ }^{\circ} \mathrm{C}$} \\
\hline $0730 \mathrm{~h}$ & 38.46 & 38.33 & 0.059 & 0.09 & 0.43 \\
\hline $1500 \mathrm{~h}$ & 39.13 & 38.84 & 0.069 & $<0.01$ & 0.30 \\
\hline $2200 \mathrm{~h}$ & 38.88 & 38.77 & 0.066 & 0.17 & 0.33 \\
\hline \multicolumn{6}{|c|}{ Skin temperature, ${ }^{\circ} \mathrm{C}$} \\
\hline Shoulder $0730 \mathrm{~h}$ & 34.43 & 34.10 & 0.124 & 0.04 & 0.41 \\
\hline Shoulder $1500 \mathrm{~h}$ & 34.96 & 34.56 & 0.144 & 0.04 & 0.90 \\
\hline Shoulder $2200 \mathrm{~h}$ & 35.40 & 35.17 & 0.083 & 0.03 & 0.71 \\
\hline Flank $0730 \mathrm{~h}$ & 34.19 & 33.88 & 0.123 & 0.07 & 0.91 \\
\hline Flank $1500 \mathrm{~h}$ & 34.66 & 34.36 & 0.107 & 0.03 & 0.85 \\
\hline Flank $2200 \mathrm{~h}$ & 34.98 & 34.50 & 0.077 & $<0.01$ & 0.22 \\
\hline \multicolumn{6}{|c|}{ Respiration rate, breaths/min } \\
\hline $0730 \mathrm{~h}$ & 55.12 & 51.16 & 1.418 & 0.03 & 0.87 \\
\hline $1500 \mathrm{~h}$ & 65.48 & 60.18 & 2.138 & 0.04 & 0.15 \\
\hline $2200 \mathrm{~h}$ & 60.77 & 55.73 & 2.325 & 0.07 & 0.83 \\
\hline
\end{tabular}

${ }^{1}$ Rectal temperature, skin temperature, and respiration rate measured on $\mathrm{d} 4$ and 7 weekly throughout the 5 -wk comparison period.

feed particles $(P=0.05)$ and in favor of particles $<8$ $\mathrm{mm}(P=0.03)$, and sorted against short particles at night $(P=0.05$; Table 11). There was minor sorting in favor of starch $(101.5 \%)$ and against NDF $(96.4 \%)$, but nutrient selection indexes did not differ $(P \geq 0.82)$ between treatments (Table 11). Feed availability and orts in periods of the day and the daily mean did not vary $(P \geq 0.18)$. The subtle differences in particle size sorting behavior did not change the nutrient composition of the consumed diet (Table 1) or the proportion of feed orts per cow (Table 11).

\section{DISCUSSION}

The rectal temperature and respiration rates were not suggestive of the occurrence of extensive heat stress. However, the sweating rate was around the maximum for cattle (Berman, 2005), the frequency of rectal temperature $\geq 39.2^{\circ} \mathrm{C}$ at $1300 \mathrm{~h}$ was $52 \%$ on CTL, and the respiratory frequency was 65 , all suggestive of some degree of heat stress. A low-energy, low-water-input, high-pressure sprinkler system with fans was used in the barn and cows were soaked with water immediately before each milking in the holding pen ( 3 times per day). Although these practices helped in body thermoregulation, some degree of not-induced heat stress apparently occurred.

The supplementation of late lactation dairy cows with YC increased the efficiency of converting DMI into milk components by reducing DMI at similar milk and solids secretion. The conversion of DOMI into ECM also tended to be increased by YC. The meta-analysis of Poppy et al. (2012) supports the concept that YC supplementation can reduce DMI of cows in mid to late lactation $(-0.78 \mathrm{~kg} / \mathrm{d})$, in agreement with our observation $(-0.90 \mathrm{~kg} / \mathrm{d})$, the opposite of the response of early lactation cows $(+0.62 \mathrm{~kg} / \mathrm{d})$. The similarity in BW and BCS between YC and CTL suggests that body tissue mobilization was not increased by the reduced DMI and DOMI on YC. Apparently, the YC supplementation increased the efficiency of energy usage for lactation and daily net energy intake was metabolically regulated.

Table 4. Proportion of cows (\% of total) with rectal temperature $\geq 39.2^{\circ} \mathrm{C}$ at 0730,1500 , and $2200 \mathrm{~h}$ on control $(\mathrm{CTL})$ and yeast $(\mathrm{YC})$ treatments $^{1}$

\begin{tabular}{lrrrrcrrr}
\hline Time, h & CTL & YC & Est $^{2}$ & SE $^{3}$ & Odds ratio & \multicolumn{2}{c}{$95 \% \mathrm{CI}^{4}$} & $P$-value \\
\hline 0730 & 8.00 & 0.06 & -2.58 & 1.047 & 0.07 & 0.009 & 0.587 & 0.01 \\
1500 & 52.00 & 24.37 & -1.21 & 0.246 & 0.29 & 0.183 & 0.482 & $<0.01$ \\
2200 & 35.33 & 25.62 & -0.46 & 0.248 & 0.63 & 0.387 & 1.027 & 0.05 \\
\hline
\end{tabular}

${ }^{1}$ Data obtained on d 4 and 7 weekly throughout the 5-wk comparison period

${ }^{2}$ Parameter estimate generated with the GENMOD procedure of SAS (ver. 9.3, SAS Institute Inc., Cary, NC) using logistic regression for binomial data. Control is zero.

${ }^{3}$ Standard error of the estimate.

${ }^{4}$ Profile likelihood $95 \%$ CI for odds ratio. 
Table 5. Body surface area, sweating rate, rectal temperature, evaporative heat loss, and total stored heat on control (CTL) and yeast (YC) treatments

\begin{tabular}{|c|c|c|c|c|c|}
\hline \multirow[b]{2}{*}{ Item } & \multirow[b]{2}{*}{ CTL } & \multirow[b]{2}{*}{$\mathrm{YC}$} & \multirow[b]{2}{*}{ SEM } & \multicolumn{2}{|c|}{$P$-value } \\
\hline & & & & Treatment & Treatment $\times$ day $^{1}$ \\
\hline Body surface area, $\mathrm{m}^{2}$ & 5.65 & 5.60 & 0.124 & 0.78 & 0.44 \\
\hline Sweating rate, ${ }^{2} \mathrm{~g} / \mathrm{m}^{2}$ per hour & 92.6 & 103.6 & 5.41 & 0.13 & 0.61 \\
\hline Rectal temperature,${ }^{3} \mathrm{C}$ & 38.8 & 38.6 & 0.06 & 0.04 & 0.27 \\
\hline Evaporative heat loss, kcal/h & 304 & 338 & 23.0 & 0.21 & 0.56 \\
\hline Total stored heat, kcal & 20.1 & 19.7 & 0.78 & 0.72 & 0.23 \\
\hline
\end{tabular}

The mechanism for the higher feed efficiency when fed YC rather than CTL did not involve increased total-tract diet digestibility or reduced ruminal acetateto-propionate ratio in ruminal fluid (representative of less methane loss per unit of digested energy). The supplementation of YC may have increased the postabsorptive conversion of metabolizable to net energy for lactation. Body temperature regulation is an energydemanding process and it is known that cows subjected to heat stress have alterations in endocrine profile and energy metabolism with higher reliance on glucose as an energy substrate (Baumgard and Rhoads, 2012).

The greater plasma niacin concentration in $\mathrm{YC}$ is a plausible explanation for the reduced rectal and skin temperatures and respiration rate, as observed by Salvati et al. (2015) in response to the supplementation of lactating cows with a product containing dead and live yeast. Cows fed $\mathrm{YC}$ had $+0.16 \mu \mathrm{g} / \mathrm{mL}$ of niacin in plasma compared with CTL, an increase of similar magnitude to the increase in plasma niacin in response to the supplementation with $12 \mathrm{~g} / \mathrm{d}$ of niacin in rumenprotected form (Zimbelman et al., 2010). Assuming a

Table 6. Jugular blood acid-base balance $8 \mathrm{~h}$ postfeeding on d 26 on control (CTL) and yeast (YC) treatments

\begin{tabular}{lrrrc}
\hline Item & CTL & \multicolumn{1}{c}{ YC } & SEM & $P$-value \\
\hline $\mathrm{pCO}_{2}{ }^{1}{ }^{1} \mathrm{~mm} \mathrm{Hg}$ & 36.90 & 37.35 & 1.123 & 0.74 \\
$\mathrm{pO}_{2}{ }^{2} \mathrm{~mm} \mathrm{Hg}$ & 30.25 & 27.69 & 1.068 & 0.10 \\
$\mathrm{pH} \mathrm{HCO}_{3}{ }^{-}, \mathrm{mmol} / \mathrm{L}$ & 7.36 & 7.38 & 0.014 & 0.24 \\
Total $^{\mathrm{CO}}{ }_{2}, \mathrm{mmol} / \mathrm{L}$ & 21.03 & 22.24 & 0.732 & 0.18 \\
$\mathrm{Base} \mathrm{excess}, \mathrm{mmol} / \mathrm{L}_{\mathrm{SatO}_{2},{ }^{3} \%} \%$ & 22.18 & 23.41 & 0.752 & 0.18 \\
$\mathrm{O}_{2} \mathrm{ct}^{,}{ }^{\%}$ & -3.28 & -2.11 & 0.873 & 0.25 \\
\hline
\end{tabular}

${ }^{1} \mathrm{pCO}_{2}=$ partial pressure of carbon dioxide.

${ }^{2} \mathrm{pO}_{2}=$ partial pressure of oxygen.

${ }^{3}$ Oxygen saturation, \% of oxygen based on total hemoglobin saturation capacity.

${ }^{4}$ Oxygen content, \% of oxygen related to the total volume of dissolved gases. 650-kg cow, $5.5 \%$ of BW of blood volume (Reynolds, 1953), and the $+0.16 \mu \mathrm{g} / \mathrm{mL}$ difference in plasma niacin concentration between treatments, the difference in circulating niacin between the 2 treatments was 5.72 $\mathrm{mg}$. Because cows consumed $1.62 \mathrm{mg}$ of niacin/d, these data suggest that the net absorption of ruminal niacin was increased in response to yeast supplementation.

The vasodilatory effects of niacin (Kamanna and Kashyap, 2008) support the trend for increased sweating rate (Di Costanzo et al., 1997; Zimbelman et al., 2010) in response to YC supplementation. The sweating rate evaluated with the cobalt chloride technique was of similar magnitude to the evaporative heat loss of cows under heat stress determined with an evapometer (Zimbelman et al., 2010). The increase in plasma glucose concentration in response to $\mathrm{YC}$ supplementation was probably the result of reduced glucose utilization by peripheral tissues in animals with alleviated body temperature (Baumgard and Rhoads, 2012) because increased glucose availability in response to $\mathrm{YC}$ supplementation would not be expected with reduced DOMI at similar ruminal fermentation profile. The reduction in rectal temperature (Bruno et al., 2009; Liu et al., 2014; Zhu et al., 2016) and the increase in plasma glucose (Liu et al., 2014) of dairy cows in response to YC supplementation have been reported. Niacin supplementation also

Table 7. Total-tract apparent digestibility (Dig.) of DM, OM, NDF, starch, and non-NDF OM, urinary allantoin excretion, and allantoin per digestible OM intake (DOMI) measured on d 27 to 29 on control $(\mathrm{CTL})$ and yeast $(\mathrm{YC})$ treatments

\begin{tabular}{lcccc}
\hline Item & CTL & YC & SEM & $P$-value \\
\hline \% of intake & & & & \\
Dig. of DM & 70.1 & 68.7 & 1.11 & 0.36 \\
Dig. of OM & 73.7 & 72.3 & 1.03 & 0.30 \\
Dig. of NDF & 49.6 & 47.8 & 0.02 & 0.51 \\
Dig. of starch & 98.1 & 97.5 & 0.36 & 0.17 \\
Dig. of non-NDF OM & 84.8 & 83.9 & 0.58 & 0.32 \\
Allantoin, mmol/d & 260 & 287 & 26.1 & 0.38 \\
Allantoin/DOMI, mmol/kg & 16.9 & 20.9 & 1.99 & 0.10 \\
\hline
\end{tabular}


Table 8. Plasma urea N (PUN) 0, 2, and 4 h postfeeding on d 34 on control (CTL) and yeast (YC) treatments

\begin{tabular}{lcccc}
\hline Item, mg/dL & CTL & YC & SEM & $P$-value \\
\hline PUN 0 h & 14.3 & 14.7 & 0.53 & 0.52 \\
PUN 2 h & 14.7 & 15.4 & 0.56 & 0.42 \\
PUN 4 h & 16.1 & 16.7 & 0.59 & 0.52 \\
\hline
\end{tabular}

reduced skin temperature, increased plasma glucose concentration, and reduced BW loss of dairy cows in early lactation (Di Costanzo et al., 1997; Wrinkle et al., 2012). Heat stress relief and improvement in lactation performance in response to $\mathrm{YC}$ supplementation have been associated with reduced expression of heat shock protein genes and increased activity of glutathione peroxidase in dairy cows (Liu et al., 2014). The positive niacin-mediated effect of $\mathrm{YC}$ supplementation on heat stress is a promising field of investigation.

Yeast culture has soluble factors such as organic acids, vitamins, and AA capable of stimulating the growth of ruminal bacteria (Callaway and Martin, 1997). Malate has been proposed as an important mediator of the positive effect of dead yeast supplementation on ruminal microbial growth (Newbold et al., 1996). The synthesis of nicotinic acid in anaerobic microbial systems uses 3- and 4-carbon precursors, such as glycerol, propionate, malate, succinate, or fumarate (Foster and Moat, 1980). A trend was observed for increased ratio of urinary allantoin to DOMI in response to YC supplementation, suggestive of increased efficiency of ruminal microbial synthesis, although no change was detected in the daily allantoin excretion. Increased microbial synthesis, without a concomitant increase in $\mathrm{OM}$ digestibility, has been reported in response to $\mathrm{YC}$ supplementation of dairy cows (Hristov et al., 2010). Increased efficiency of microbial synthesis in the rumen was positively associated with niacin flow to the duodenum of dairy cows (Beaudet et al., 2016).

It has been proposed that feed sorting behavior of lactating cows would respond to changes in rumen

Table 9. Molar proportion of VFA, $\mathrm{pH}$, and protozoa concentration in rumen fluid on d 35 on control (CTL) and yeast (YC) treatments

\begin{tabular}{lrrrc}
\hline Item & CTL & YC & SEM & $P$-value \\
\hline \% of VFA & & & & \\
Acetate & 59.9 & 59.1 & 0.67 & 0.43 \\
Propionate & 25.2 & 26.1 & 0.79 & 0.43 \\
Butyrate & 9.9 & 9.5 & 0.21 & 0.27 \\
Valerate & 1.9 & 2.1 & 0.09 & 0.28 \\
Isovalerate & 2.2 & 2.4 & 0.07 & 0.48 \\
Isobutyrate & 0.8 & 0.8 & 0.03 & 0.53 \\
Acetate/propionate & 2.44 & 2.28 & 0.107 & 0.31 \\
pH & 6.47 & 6.51 & 0.087 & 0.77 \\
Protozoa, $\times 10^{4} / \mathrm{mL}$ & 5.86 & 4.81 & 0.874 & 0.38 \\
\hline
\end{tabular}

Table 10. Chewing activity, intake pattern, and time laying down on d 30 to 32 on control (CTL) and yeast (YC) treatments

\begin{tabular}{lcccc}
\hline Item & CTL & YC & SEM & $P$-value \\
\hline Ingestion, min/d & 322 & 333 & 13.5 & 0.57 \\
Rumination, min/d & 461 & 455 & 17.4 & 0.79 \\
Chewing, ${ }^{1}$ min/d & 783 & 779 & 22.2 & 0.88 \\
Ingestion, min/kg of DMI & 14.1 & 15.5 & 0.74 & 0.22 \\
Rumination, min/kg of DMI & 20.8 & 23.4 & 1.25 & 0.17 \\
Chewing, ${ }^{1}$ min/kg of DMI & 34.4 & 37.1 & 1.87 & 0.27 \\
First meal duration, min & 41.9 & 49.8 & 4.43 & 0.18 \\
Meals/d & 10.2 & 10.7 & 0.48 & 0.35 \\
Meal duration, min & 32.5 & 32.6 & 1.26 & 0.97 \\
Intermeal interval, min & 126 & 120 & 6.6 & 0.42 \\
Laying time, min/d & 660 & 678 & 25.2 & 0.68 \\
\hline
\end{tabular}

${ }^{1}$ Chewing = ingestion + rumination.

environment (DeVries et al., 2008). The supplementation of dairy cows with live yeast induced refusal of long feed particles, increased the number of meals per day, and reduced the interval between meals (DeVries and Chevaux, 2014), possibly due to the stabilization of ruminal pH. Allen and Ying (2012) also detected an increase in the number of meals and in meal duration in response to $\mathrm{YC}$. The absence of an effect of $\mathrm{YC}$ on meal duration and size in our experiment is consistent with the lack of a treatment effect on ruminal fermentation profile. The minor difference between treatments in feed particle sorting and the similarity in starch and NDF sorting behavior also support this observation. The response in ruminal fermentation profile to yeast supplementation is not consistent. The meta-analysis of Desnoyers et al. (2009) suggested an expected increase of +0.03 in rumen $\mathrm{pH}$ of ruminants supplemented with yeast products, a trend for a reduction of $-0.8 \mu M$

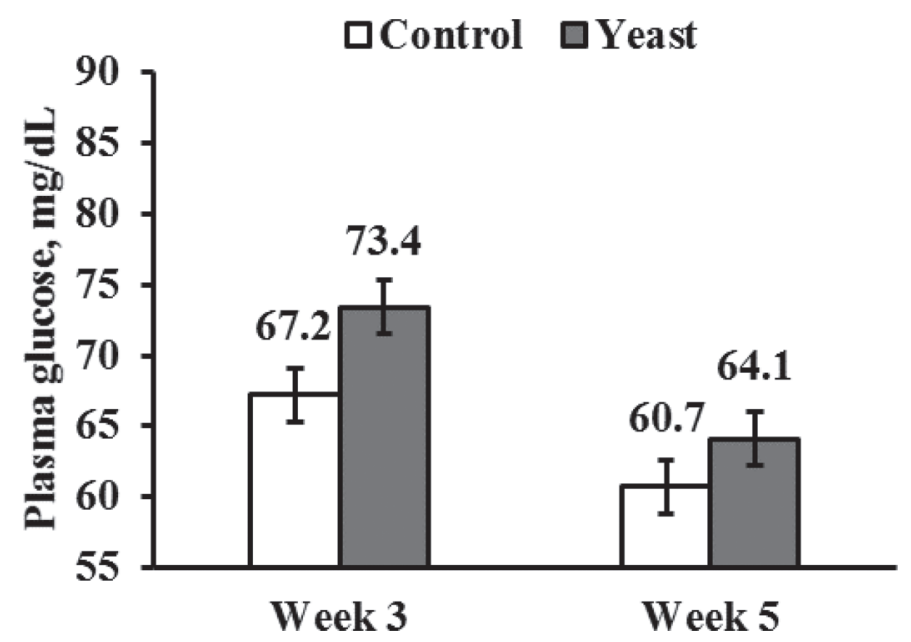

Figure 4. Plasma glucose concentration on wk 3 and 5 at $12 \mathrm{~h}$ postfeeding on control and yeast treatments. $P=0.01$ for the effect of treatment, $P<0.01$ for the effect of week, and $P=0.45$ for the interaction of treatment and week. Error bars represent SEM. 
Table 11. Proportion of intake in periods of the day and feed sorting behavior on d 30 to 32 on control (CTL) and yeast $(\mathrm{YC})$ treatments

\begin{tabular}{|c|c|c|c|c|}
\hline Item & CTL & $\mathrm{YC}$ & SEM & $P$-value \\
\hline 0700 to $1300 \mathrm{~h}, \%$ of daily intake & 36.1 & 36.8 & 2.11 & 0.80 \\
\hline 1300 to $1900 \mathrm{~h}, \%$ of daily intake & 41.7 & 43.1 & 2.41 & 0.66 \\
\hline 1900 to $0700 \mathrm{~h}, \%$ of daily intake & 22.3 & 20.1 & 2.25 & 0.49 \\
\hline \multicolumn{5}{|l|}{ Observed/predicted, ${ }^{1} \%$} \\
\hline \multicolumn{5}{|l|}{0700 to $1300 \mathrm{~h}$} \\
\hline$>19 \mathrm{~mm}$ & 71.9 & 97.9 & 7.23 & 0.02 \\
\hline 8 to $19 \mathrm{~mm}$ & 96.0 & 96.4 & 2.27 & 0.92 \\
\hline$<8 \mathrm{~mm}$ & 105.3 & 105.4 & 1.35 & 0.98 \\
\hline \multicolumn{5}{|l|}{1300 to $1900 \mathrm{~h}$} \\
\hline$>19 \mathrm{~mm}$ & 89.0 & 65.6 & 8.05 & 0.05 \\
\hline 8 to $19 \mathrm{~mm}$ & 100.9 & 100.0 & 2.76 & 0.83 \\
\hline$<8 \mathrm{~mm}$ & 102.6 & 109.9 & 2.29 & 0.03 \\
\hline \multicolumn{5}{|l|}{1900 to $0700 \mathrm{~h}$} \\
\hline$>19 \mathrm{~mm}$ & 121.0 & 117.7 & 10.01 & 0.82 \\
\hline 8 to $19 \mathrm{~mm}$ & 96.0 & 96.9 & 4.36 & 0.88 \\
\hline$<8 \mathrm{~mm}$ & 101.4 & 91.3 & 3.42 & 0.05 \\
\hline Sorting of starch & 101.5 & 101.6 & 0.84 & 0.95 \\
\hline Sorting of NDF & 97.1 & 96.1 & 0.85 & 0.82 \\
\hline \multicolumn{5}{|l|}{ TMR and refusals (as-fed basis) } \\
\hline TMR $0700 \mathrm{~h}, \mathrm{~kg}$ & 28.0 & 28.0 & & \\
\hline Refusal $1300 \mathrm{~h}, \mathrm{~kg}$ & 12.9 & 13.3 & 1.11 & 0.80 \\
\hline Refusal 0700 to 1300 h, \% of offered & 46.1 & 47.6 & 0.04 & 0.79 \\
\hline TMR $1300 \mathrm{~h},{ }^{2} \mathrm{~kg}$ & 39.4 & 36.2 & 1.81 & 0.18 \\
\hline Refusal $1900 \mathrm{~h}, \mathrm{~kg}$ & 21.7 & 19.5 & 1.48 & 0.28 \\
\hline Refusal 1300 to 1900 h, \% of offered & 54.9 & 53.7 & 0.03 & 0.76 \\
\hline Refusal 0700 h, kg & 12.3 & 11.6 & 1.19 & 0.70 \\
\hline Refusal 1900 to 0700 h, \% of offered & 56.7 & 59.3 & 0.04 & 0.69 \\
\hline Daily refusal, ${ }^{3} \%$ of offered & 22.5 & 23.5 & 2.38 & 0.77 \\
\hline
\end{tabular}

${ }^{1}<100 \%=$ rejection, $>100 \%=$ preferential intake, $100 \%=$ no selection.

${ }^{2}$ TMR $1300 \mathrm{~h}=$ refusal $1300 \mathrm{~h}+$ offered TMR $1300 \mathrm{~h}$

${ }^{3}$ Daily refusal $=($ refusal $0700 \mathrm{~h} /$ offered daily TMR $) \times 100$.

in ruminal lactate concentration, and an increase in total-tract $\mathrm{OM}$ digestibility of +0.8 percentage units, all differences of low biological magnitude. In this experiment, no evidence indicated that the gain in feed efficiency induced by YC supplementation was driven by modulation of ruminal fermentation profile or totaltract nutrient digestibility.

The greater respiration rate of cows fed the CTL is consistent with the trend for increased partial pressure of $\mathrm{O}_{2}$ of jugular blood, although acid-base balance was similar to YC. The alleviation of heat stress by YC supplementation apparently was not of sufficient magnitude to elicit changes in saliva buffering capacity (Schneider et al., 1988), at similar rumination time. Laying time also did not respond to YC, suggesting that the reduction in body temperature was not capable of affecting cow posture.

Supplementation with YC did not affect milk SCC. No evidence indicated that YC supplementation could induce gain in nonspecific immunomodulation by cell wall polysaccharides and protein (Moran, 2004) in this experiment, although a thorough evaluation of the immune response to YC supplementation was not performed. Yeast cell wall components may have been extensively degraded in the rumen or our cows simply did not have a high enough SCC (184,000 cells/mL) to benefit from YC supplementation.

\section{CONCLUSIONS}

Improved thermal comfort and increased feed efficiency were observed in response to feeding dead yeast culture to lactating dairy cows in late lactation during the Brazilian hot season. Yeast culture supplementation increased plasma niacin and glucose concentrations, reduced rectal and skin temperatures and respiration rate, and increased feed efficiency by reducing DMI at similar milk yield. The positive effect of YC supplementation on feed efficiency was metabolically mediated, instead of driven by change in nutrient digestibility and ruminal fermentation profile.

\section{ACKNOWLEDGMENTS}

The authors are grateful to FAPEMIG (Minas Gerais Foundation for Research Support, Belo Horizonte, Bra-

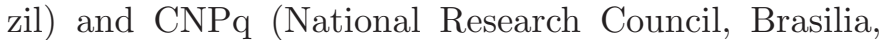
Brazil) for the grants to the authors, to GRASP In- 
dústria e Comércio Ltda (Curitiba, Brazil) for partially funding the project, to the members of Grupo do Leite of the University of Lavras for the help in data collection and animal care, and to Luciana Castelar Tsuda and Alexandre Vaz Pires (Luiz de Queiroz College of Agriculture, University of Sao Paulo, Piracicaba, Brazil) for the GC analysis of VFA.

\section{REFERENCES}

Allen, M. S., and Y. Ying. 2012. Effects of Saccharomyces cerevisiae fermentation product on ruminal starch digestion are dependent upon dry matter intake for lactating cows. J. Dairy Sci. 95:65916605 .

AOAC International. 2012. Official Methods of Analysis. 19th ed. AOAC International. Gaithersburg, MD

Baumgard, L. H., and R. P. Rhoads. 2012. Ruminant production and metabolic responses to heat stress. J. Anim. Sci. 90:1855-1865.

Beaudet, V., R. Gervais, B. Graulet, P. Nozière, M. Doreau, A. Fanchone, and D. D. S. Castagnino. 2016. Effects of dietary nitrogen levels and carbohydrate sources on apparent ruminal synthesis of some B vitamins in dairy cows. J. Dairy Sci. 99:2730-2739.

Berman, A. 2005. Estimates of heat stress relief needs for Holstein dairy cows. J. Anim. Sci. 83:1377-1384.

Bradford, B. J., K. Yuan, J. K. Farney, L. K. Mamedova, and A. J. Carpenter. 2015. Invited review: Inflammation during the transition to lactation: New adventures with an old flame. J. Dairy Sci. 98:6631-6650.

Bruno, R. G. S., H. M. Rutigliano, R. L. Cerri, P. H. Robinson, and J. E. P. Santos. 2009. Effect of feeding Saccharomyces cerevisiae on performance of dairy cows during summer heat stress. Anim. Feed Sci. Technol. 150:175-186.

Callaway, E. S., and S. A. Martin. 1997. Effects of a Saccharomyces cerevisiae culture on ruminal bacteria that utilize lactate and digest cellulose. J. Dairy Sci. 80:2035-2044.

Chaucheyras-Durand, F., N. D. Walker, and A. Bach. 2008. Effects of active dry yeasts on the rumen microbial ecosystem: Past, present and future. Anim. Feed Sci. Technol. 145:5-26.

Chen, X. B., and M. J. Gomes. 1992. Estimation of microbial protein supply to sheep and cattle based on urinary excretion of purine derivatives: An overview of technical details. Int. Feed Res. Unit, Occasional Publ. Rowett Research Institute, Aberdeen, United Kingdom.

Dehority, B. A. 1984. Evaluation of subsampling and fixation procedures used for counting rumen protozoa. Appl. Environ. Microbiol. 48:182-185.

Desnoyers, M., S. Giger-Reverdin, G. Bertin, C. Duvaux-Ponter, and D. Sauvant. 2009. Meta-analysis of the influence of Saccharomyces cerevisiae supplementation on ruminal parameters and milk production of ruminants. J. Dairy Sci. 92:1620-1632.

DeVries, T. J., and E. Chevaux. 2014. Modification of the feeding behavior of dairy cows through live yeast supplementation. J. Dairy Sci. 97:6499-6510.

DeVries, T. J., F. Dohme, and K. A. Beauchemin. 2008. Repeated ruminal acidosis challenges in lactating dairy cows at high and low risk for developing acidosis: Feed sorting. J. Dairy Sci. 91:39583967.

Di Costanzo, A., J. N. Spain, and D. E. Spiers. 1997. Supplementation of nicotinic acid for lactating Holstein cows under heat stress conditions. J. Dairy Sci. 80:1200-1206.

Dohme, F., T. J. Devries, and K. A. Beauchemin. 2008. Repeated ruminal acidosis challenges in lactating dairy cows at high and low risk for developing acidosis: Ruminal pH. J. Dairy Sci. 91:35543567.

Ferreira, E. M., A. V. Pires, I. Susin, M. V. Biehl, R. S. Gentil, M. O. M. Parente, D. M. Polizel, C. V. M. R. Ribeiro, and E. Almeida. 2016. Nutrient digestibility and ruminal fatty acid metabolism in lambs supplemented with soybean oil partially replaced by fish oil blend. Anim. Feed Sci. Technol. 216:30-39.

Foster, J. W., and A. G. Moat. 1980. Nicotinamide adenine dinucleotide biosynthesis and pyridine nucleotide cycle metabolism in microbial systems. Microbiol. Rev. 44:83-105.

Fuquay, J. W. 1981. Heat stress as it affects animal production. J. Anim. Sci. 52:164-174.

Hall, M. B. 2009. Analysis of starch, including maltooligosaccharides in animal feeds: A comparison of methods and a recommended method for AOAC collaborative study. J. AOAC Int. 92:42-49.

Hristov, A. N., G. Varga, T. Cassidy, M. Long, K. Heyler, S. K. R. Karnati, B. Corl, C. J. Hovde, and I. Yoon. 2010. Effect of Saccharomyces cerevisiae fermentation product on ruminal fermentation and nutrient utilization in dairy cows. J. Dairy Sci. 93:682-692.

Huber, J. T., G. Higginbotham, A. Gomez-Alarcon, R. B. Taylor, K. H. Chen, S. C. Chan, and Z. Wu. 1994. Heat stress interactions with protein, supplemental fat, and fungal cultures. J. Dairy Sci. 77:2080-2090.

Kadzere, C. T., M. R. Murphy, N. Silanikove, and E. Maltz. 2002. Heat stress in lactating dairy cows: A review. Livest. Prod. Sci. 77:59-91

Kamanna, V. S., and M. L. Kashyap. 2008. Mechanism of action of niacin. Am. J. Cardiol. 101:S20-S26.

Lee, S. S., F. M. Robinson, and Y. Wang. 1981. Rapid determination of yeast viability. Pages 641-649 in Biotechnol. Bioeng. Symp. Vol. 11. Univ. of Michigan, Ann Arbor.

Leonardi, C., and L. E. Armentano. 2003. Effect of quantity, quality, and length of alfalfa hay on selective consumption by dairy cows. J. Dairy Sci. 86:557-564.

Littell, R. C., P. R. Henry, and C. B. Ammerman. 1998. Statistical analysis of repeated measures data using SAS procedures. J. Anim. Sci. 76:1216-1231.

Liu, J., G. Ye, Y. Zhou, Y. Liu, L. Zhao, X. Chen, D. Huang, S. F. Liao, and K. Huang. 2014. Feeding glycerol-enriched yeast culture improves performance, energy status, and heat shock protein gene expression of lactating Holstein cows under heat stress. J. Anim. Sci. 92:2494-2502.

McLean, J. A. 1963. The partition of insensible losses of body weight and heat from cattle under various climatic conditions. J. Physiol. $167: 427-447$.

Mishra, M., F. A. Martz, R. W. Stanley, H. D. Johnson, J. R. Campbell, and E. Hilderbrand. 1970. Effect of diet and ambient temperature-humidity on ruminal $\mathrm{pH}$, oxidation reduction potential, ammonia and latic acid in lactating cows. J. Anim. Sci. 30:1023-1028.

Moallem, U., H. Lehrer, L. Livshitz, M. Zachut, and S. Yakoby. 2009 The effects of live yeast supplementation to dairy cows during the hot season on production, feed efficiency, and digestibility. J. Dairy Sci. 92:343-351.

Moran, C. A. 2004. Functional components of cell wall of Saccharomyces cerevisiae applications for yeast glucan and mannan. Pages 283-296 in Nutritional Biotechnology in the Feed and Food Industries. T. P. Lyons and K. A. Jacques, ed. Notthingham University Press, Thrumpton, United Kingdom.

Mullins, C. R., L. K. Mamedova, M. J. Brouk, C. E. Moore, H. B Green, K. L. Perfield, J. F. Smith, J. P. Harner, and B. J. Bradford. 2012. Effects of monensin on metabolic parameters, feeding behavior, and productivity of transition dairy cows. J. Dairy Sci. 95:1323-1336.

Newbold, C. J., R. J. Wallace, and F. M. McIntosh. 1996. Mode of action of the yeast Saccharomyces cerevisiae as a feed additive for ruminants. Br. J. Nutr. 76:249-261.

NRC. 2001. Nutrient Requirements of Dairy Cattle. 7th rev. ed. Natl. Acad. Sci., Washington, DC.

Poppy, G. D., A. R. Rabiee, I. J. Lean, W. K. Sanchez, K. L. Dorton, and P. S. Morley. 2012. A meta-analysis of the effects of feeding yeast culture produced by anaerobic fermentation of Saccharomyces cerevisiae on milk production of lactating dairy cows. J. Dairy Sci. 95:6027-6041.

Reynolds, M. 1953. Plasma and blood volume in the cow using the T-1824 hematocrit method. Am. J. Physiol. 173:421-427. 
Rhoads, M. L., R. P. Rhoads, M. J. VanBaale, R. J. Collier, S. R. Sanders, W. J. Weber, B. A. Crooker, and L. H. Baumgard. 2009 Effects of heat stress and plane of nutrition on lactating Holstein cows: I. Production, metabolism, and aspects of circulating somatotropin. J. Dairy Sci. 92:1986-1997.

Salvati, G. G. S., N. N. Morais Júnior, A. C. S. Melo, R. R. Vilela, F. F. Cardoso, M. Aronovich, R. A. N. Pereira, and M. N. Pereira. 2015. Response of lactating cows to live yeast supplementation during summer. J. Dairy Sci. 98:4062-4073.

Sawka, M. N., and J. W. Castellani. 2007. How hot is the human body? J. Appl. Physiol. 103:419-420.

Schingoethe, D. J., K. N. Linke, K. F. Kalscheur, A. R. Hippen, D. R. Rennich, and I. Yoon. 2004. Feed efficiency of mid-lactation dairy cows fed yeast culture during summer. J. Dairy Sci. 87:4178-4181.

Schleger, A. V., and H. G. Turner. 1965. Sweating rates of cattle in the field and their reaction. Aust. J. Agric. Res. 16:92-106.

Schneider, P. L., D. K. Beede, and C. J. Wilcox. 1988. Nycterohemeral patterns of acid-base status, mineral concentrations and digestive function of lactating cows in natural or chamber heat stress environments. J. Anim. Sci. 66:112-125.

Shwartz, G., M. L. Rhoads, M. J. VanBaale, R. P. Rhoads, and L. H. Baumgard. 2009. Effects of a supplemental yeast culture on heatstressed lactating Holstein cows. J. Dairy Sci. 92:935-942.

Silanikove, N. 2000. Effects of heat stress on the welfare of extensively managed domestic ruminants domestic ruminants. Livest. Prod. Sci. $67: 1-18$.

St. Pierre, N. R., B. Cobanov, and G. Schnitkey. 2003. Economic losses from heat stress by US livestock industries. J. Dairy Sci. 86:E52E77.

Van Soest, P. J., J. B. Robertson, and B. A. Lewis. 1991. Methods for dietary fiber, neutral detergent fiber, and nonstarch polysaccharides in relation to animal nutrition. J. Dairy Sci. 74:3583-3597.
Warner, A. C. I. 1962. Enumeration of rumen micro-organisms. J. Gen. Microbiol. 28:119-128.

Wildman, E. E., G. M. Jones, P. E. Wagner, R. L. Boman, H. F. Troutt, and T. N. Lesch. 1982. A dairy cow body condition scoring system and its relationship to selected production characteristics. J. Dairy Sci. 65:495-501.

Wrinkle, S. R., P. H. Robinson, and J. E. Garrett. 2012. Niacin delivery to the intestinal absorptive site impacts heat stress and productivity responses of high producing dairy cows during hot conditions. Anim. Feed Sci. Technol. 175:33-47.

Yousef, M. K. 1985. Stress Physiology in Livestock. 1st ed. CRC Press Inc., Boca Raton, FL.

Zaworski, E. M., N. A. Fadden, W. K. Sanchez, I. Yoon, and G. Bobe. 2014. Effects of feeding various dosages of Saccharomyces cerevisiae fermentation product in transition dairy cows. J. Dairy Sci 97:3081-3098

Zhu, W., B. X. Zhang, K. Y. Yao, I. Yoon, Y. H. Chung, J. K. Wang, and J. X. Liu. 2016. Effects of supplemental levels of Saccharomyces cerevisiae fermentation product on lactation performance in dairy cows under heat stress. Asian-Australas. J. Anim. Sci 29:801-806.

Zimbelman, R. B., L. H. Baumgard, and R. J. Collier. 2010. Effects of encapsulated niacin on evaporative heat loss and body temperature in moderately heat-stressed lactating Holstein cows. J. Dairy Sci. 93:2387-2394.

Zimbelman, R. B., R. J. Collier, and T. R. Bilby. 2013. Effects of utilizing rumen protected niacin on core body temperature as well as milk production and composition in lactating dairy cows during heat stress. Anim. Feed Sci. Technol. 180:26-33. 